\title{
Survival of Cool-Season Species under
}

\section{Texas-Pecos Conditions}

\author{
GARY S. KEMPH, JOSEPH L. \\ SCHUSTER, AND TOMMY G. \\ WELCH
}

Highlight: Four cool-season species were grown for I year under controlled conditions simulating a dry, a typical, and a wet fall planting season in far west Texas. Crested wheatgrass and Russian wildrye had higher survival percentages than sideoats grama at the end of the study. Both species appear capable of reducing the cool-season forage shortage in the TransPecos region of Texas. Neither wintergreen hardinggrass nor burnet appear adapted to the Trans-Pecos. Seedling morphology did not affect plant survival.

A shortage of cool-season range forage in the Trans-Pecos land resource area of far west Texas necessitates costly supplemental livestock feeding. Sparse winter and spring moisture is the primary cause of the shortage. A plant species that would lengthen the green forage period would help reduce feed costs. Attempts to introduce coolseason forage species have been largely unsuccessful, either due to the lack of adapted species or low establishment success in the harsh environment. Seedling survival under harsh environmental conditions has been related to various plant morphological characteristics, particularly presence or absence of an elongated subcoleoptile internode in range grasses (Hyder et al., 1971).

The purpose of our study was to evaluate selected cool-season forage species for possible range seeding in

\footnotetext{
Authors are research assistant, Department of Range Science, Texas A\&M University, College Station, Texas; professor and head, Department of Range Science, Texas A\&M University, College Station, Texas; area range and brush control specialist, Texas Agricultural Extension Service of the Texas A\&M University System, Vernon, Texas.

The report is published with approval of the director, Texas Agricultural Experiment Station as technical article TA 12009. Project data were also used by the senior author in partial fulfillment of the requirements for a Master of Science degree.

The authors wish to thank Mr. Gene Jones of Chilllicothe Ranch, Valentine, Tex., for his assistance with this study.

Manuscript received August 23, 1975
}

the Trans-Pecos, and to determine the correlation between plant survival and various plant growth parameters in a controlled environment chamber.

\section{Materials and Methods}

Thirteen species initially were evaluated relative to establishment and survival on the Chillicothe Ranch, $90 \mathrm{~km}$ west of Marfa, Tex. Plots were established on a rootplowed overflow deep upland range site with a Musquiz loam soil. Elevation of the site is $1,500 \mathrm{~m}$ and mean annual precipitation at Marfa is about $36 \mathrm{~cm}$. Most precipitation occurs in late summer and early fall. Vegetation on the deep upland range site surrounding the plots included tobosagrass (Hilaria mutica), sideoats grama (Bouteloua curtipendula), buffalograss (Buchloe dactyloides), and various annual grasses and forbs.

In 13 species of cool-season grasses, forbs, and browse were planted in 76- $\mathrm{cm}$ rows at $13 \mathrm{~mm}$ depth in late August, 1972. At first frost in early December, the four species exhibiting the highest emergence, survival, and leaf production were selected for further study in the controlled environment chamber. The $7 \mathrm{~cm}$ of precipitation received on the plots during the 3-month pilot study was below average.

Species selected for further study in the controlled environment chamber were crested wheatgrass (Agropyron cristatum (L.) Gaertn.), Russian wildrye (Elymus junceus Fisch.), wintergreen hardinggrass (Phalaris tuberosa var. stenoptera (Hack.) Hitch cv. TAM), all of which are grasses, and burnet (Sanguisorba minor Scop.), a forb. Sideoats grama (Bouteloua curtipendula (Michx.) Torr. cv. Premier) was used for comparison due to its known adaptability to the Marfa area.

The controlled environment chamber was programmed as closely as possible to climatological data from Marfa, Tex., for the period from August 1, 1972, to July 31 , 1973, published by the U.S. Department of Commerce (1972, 1973). Air temperature was programmed using 2-week averages for the daily 12-hour high and 12-hour low temperature cycle. Photoperiod was programmed using the 2-week average daylength for the Marfa latitude. Light intensity was controlled with timed light banks containing both fluorescent and incandescent bulbs. Photosynthetically active light (400 to $700 \mathrm{~nm}$ wavelength) intensity averaged $220 \mathrm{kergs} / \mathrm{m}^{2} \mathrm{sec}$ at the soil surface. Relative humidity was programmed at $40 \%$ and $70 \%$ during the daily high and low temperature periods, respectively. Three precipitation regimes, 75,100 , and $150 \%$ of daily-recorded precipitation, were applied with a syringe until first frost, then a single $100 \%$ regime was applied through the end of the study. Precipitation totals under each regime were 41,46 , and $56 \mathrm{~cm}$, respectively.

A representative sample of soil was collected from the Chillicothe Ranch test plots, screened, and 1,200 g placed in each of 180 plastic bags. The bags were packed side-by-side in a large wooden box to provide mutual insulation in the controlled environment chamber. The soil was packed to uniform density, and seven pure live seed were planted at $13 \mathrm{~mm}$ depth in each container. Thirty-six containers were planted for each species. Seedlings were thinned to five per container after 21 days.

Plant samples were collected 32 days, 120 days (first frost), 248 days (last frost), and 365 days (beginning of fall rainy season) after planting. Three samples of each species-precipitation regime combination were evaluated on each sampling date. Measurements included percent emergence, percent survival, shoot and root weight, number of adventitious roots, number of tillers, crown depth, subcoleoptile internode length, coleoptile length, and length of longest leaf per plant.

The experimental design was completely random with a factorial arrangement of treatments and three replications per treatment. A treatment consisted of a combination of plant species, precipitation regime, and collection date. Data were subjected to analysis of variance and factor effects were evaluated using orthogonal 


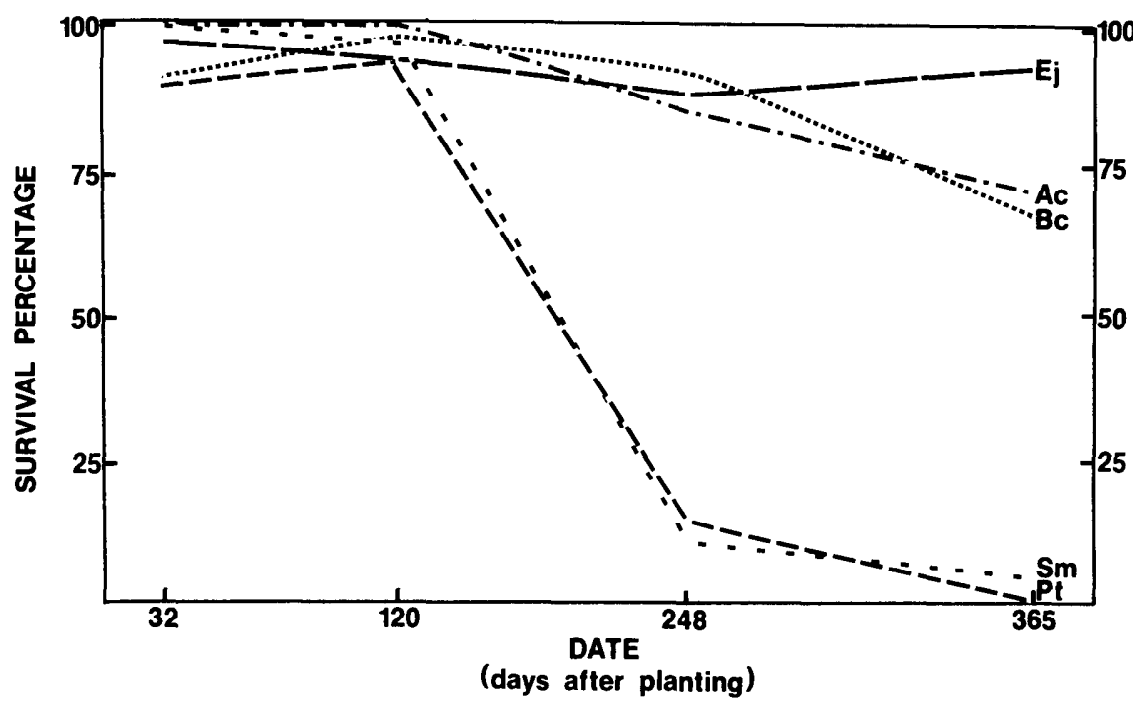

Fig. 1. Average seedling survival (\%) on four dates for five species averaged over three precipitation regimes in the controlled environment study of cool-season species for range seeding in the TransPecos. $A c=$ Agropyron cristatum, $E j=$ Elymus junceus, $B c=$ Bouteloua curtipendula, $P t=$ Phalaris tuberosa, and $S m=$ Sanguisorba minor. contrasts. Correlation coefficients were determined for selected parameters.

\section{Results and Discussion}

Russian wildrye had the highest survival percentage under each of the three precipitation regimes after 365 days (Fig. 1). Survival percentage after 365 days was negatively correlated with fall (120-day) root weights $(r=-.65)$, adventitious root numbers $(r=-.59)$, and shoot weights $(r=-.45)$. The association of smaller fall plants with year-end survival was also noted in sideoats grama, which had the heaviest average shoot weight of all species (Fig. 2). Previous research on individual species indicated that larger fall plants were normally better adapted for winter survival than were smaller plants (Troughton, 1957). The opposite results of this study could be attributed to differential growth as influenced by precipitation regime. The smallest Russian wildrye and sideoats grama plants were grown under the driest regime, and the largest plants were grown under the higher precipitation regimes. Plants grown under drouth conditions during early development normally are physiologically hardened and better able to survive severe drouths than are plants grown under more optimum moisture conditions (Hsiao, 1973). Higher survival percentages of Russian wildrye and sideoats grama indicate that under the driest regime of this study physiological hard-

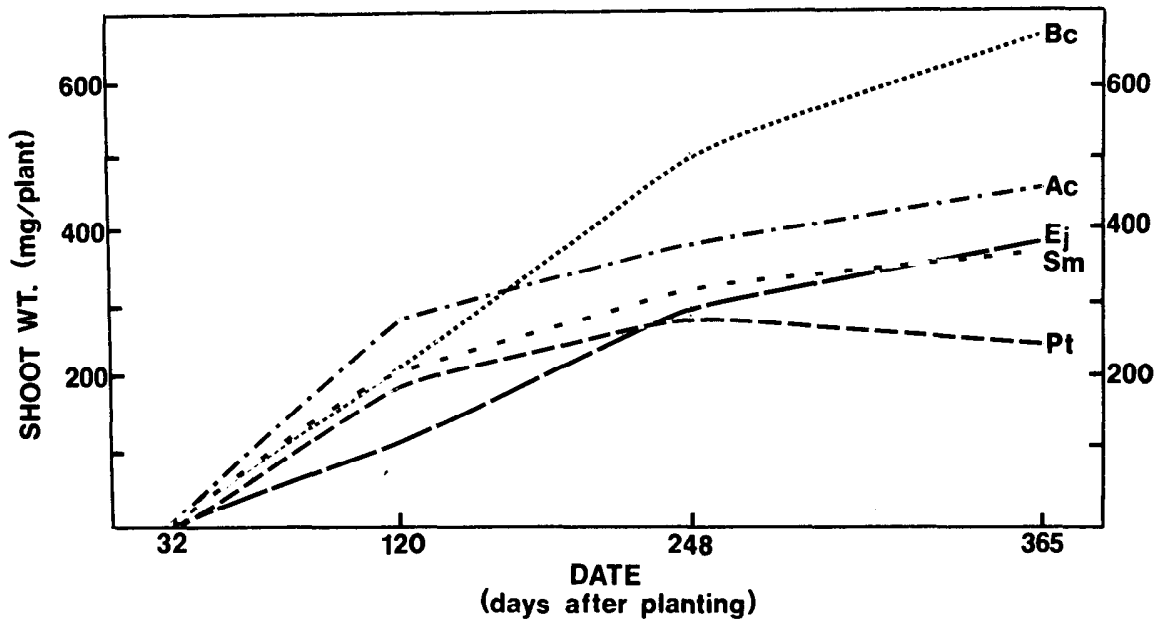

Fig. 2. Average shoot weight (mg/plant) on four dates for five species averaged over three precipitation regimes in the controlled environment evaluation of cool-season species for range seeding in the Trans-Pecos. Ac $=$ Agropyron cristatum, $E j=$ Elymus junceus, $B c=$ Bouteloua curtipendula, $P t=$ Phalaris tuberosa, and $S m=$ Sanguisorba minor. ening may have been an important factor in survival of these species.

Crested wheatgrass had the second highest average survival percentage after 365 days.Contrary to the findings for Russian wildrye and sideoats grama, crested wheatgrass survival was positively correlated with heavier fall root weights $(r=.33)$, shoot weights $(r=.41)$, and numbers of adventitious roots $(r=.47)$. Thus crested wheatgrass survival was favored more than the other species by rapid root and shoot development after germination. Its year-end survival correlated positively with 32-day root weights $(r=$ $.50)$, numbers of adventitious roots ( $r$ $=.60)$, shoot weights $(r=.47)$, and lengths of longest leaves $(r=.53)$.

Crested wheatgrass survival and rootweight responses to increased precipitation regime were much higher than that of the other species. These results indicate that crested wheatgrass survival is favored by high fall precipitation and the resulting development of large roots and shoots prior to winter.

Premier sideoats grama had a slightly lower average survival percentage than crested wheatgrass at the end of the study. Year-end survival was negatively correlated with fall root weights $(r=-.79)$, adventitious root numbers $(r=-.41)$, and shoot weights $(r=$ $-.65)$. There was also a negative correlation of survival with root weights $(r=$ $-.70)$, and shoot weights $(r=-.47)$ 32 days after planting, and fall tiller numbers $(r=-.56)$. Sideoats grama had $100 \%$ seedling survival and relatively small plants under the driest precipitation regime, as did Russian wildrye. The data indicate that physiological hardening may have been important in sideoats grama survival in this study, as it apparently was with Russian wildrye. Sideoats grama and Russian wildrye should be better able than the other species studied to survive fall plantings in years with below-average fall precipitation.

No wintergreen hardinggrass plants survived the first year of growth. Most of the plants $(87 \%)$ died during the winter and the remaining plants died during the spring-summer, between the 248-day and 365-day sampling dates. There were no apparent differences among the growth parameters meassured which could account for the large differences in survival percentages between wintergreen hardinggrass and the other grasses. Survival of wintergreen 


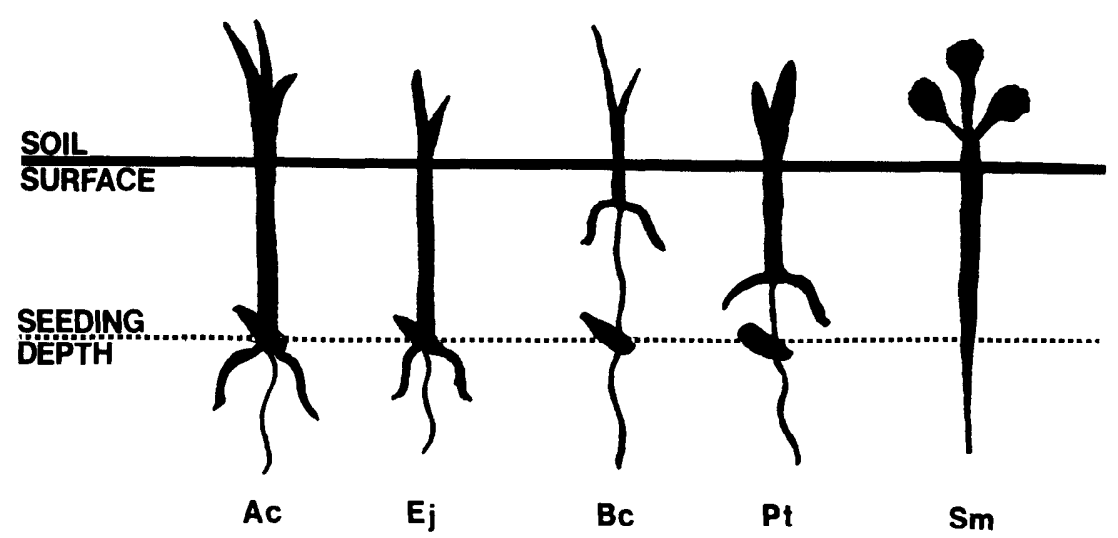

Fig. 3. Typical seedling morphology of the five species studied for range seeding in the TransPecos. $A c=$ Agropyron cristatum, $E j=$ Elymus junceus, $B C=$ Bouteloua curtipendula, $P t=$ Phalaris tuberosa, and $S m=$ Sanguisorba minor. Note elongated subcoleoptile internode on $B c$ and $P t$.

hardinggrass was reported to be adversely affected by dry winters and low soil nitrogen (U.S. Dep. Agr., 1972; Brown and Pratt, 1972). Winter precipitation in this study totaled $6.2 \mathrm{~cm}$ for the period November through April, much lower than that for the more eastern areas of Texas where this species is known to be adapted. Soil tests indicated that the soil used in this study was low in nitrogen. Thus low winter precipitation or low soil nitrogen may have adversely affected wintergreen hardinggrass survival in this study.

Only $4 \%$ of the burnet plants survived at the end of the study. Most of the plants $(89 \%)$ died during the winter and all but $4 \%$ died by the end of the spring-summer. The limited information available on burnet indicates that it is best adapted to areas with higher winter precipitation than that of the Trans-Pecos (U.S. Dep. Agr., 1972). Limited winter precipitation could have caused the high burnet seedling mortality observed under the Trans-Pecos environmental conditions simulated in this study.

Presence or absence of an elongated subcoleoptile internode was not an important factor in plant survival in this study (Fig. 3). In general crested wheatgrass and Russian wildrye, with no internode elongation, had higher survival percentages than did sideoats grama and wintergreen hardinggrass, with elongation. Sideoats grama which had the longest subcoleoptile internodes, had as high a survival percentage as either of the wo species with no elongation when grown under the driest regime. This indicates that presence or absence of an elongated subcoleoptile internode was not a dominant factor in plant survival in the harsh environmental conditions of this study.

Based on these controlled environment results, crested wheatgrass and Russian wildrye apparently are adapted to the Trans-Pecos region of west Texas. Further study is required to evaluate their adaptability under actual field conditions before planting recommendations can be made.

\section{Literature Cited}

Brown, M. H., and J. N. Pratt, 1972. TAM wintergreen hardinggrass. Tex. Agr. Prog. 18:14-15.

Hsiao, T. C. 1973. Plant responses to water Annu. Rev. Plant Physiol. 24:519-570.

Hyder, D. N., A. C. Everson, and R. E. Bement. 1971. Seedling morphology and seedling failures with blue grama. J. Range Manage. 24:287-292.

Troughton, A. 1957. The underground organs of herbage grasses. Commonwealth Bur. Pasture and Field Crops Bull. 44. Hurley, Berkshire, England. 1630.

U.S. Department of Agriculture. 1972. Grass varieties in the United States. U.S. Dep. Agr. Handbook 170. $168 \mathrm{p}$.

U.S. Department of Commerce. 1972 (8-12) and 1973 (1-7). Climatological data, Texas. U.S. Dep. Commerce, Washington, D.C.

\section{Indexes to JRM:}

Complete author, title, and subject matter indexes are available for the first 20 volumes of the Journal of Range Management.

Index No. 1 for Vols. 1-10(1948-57)@ @ 1.00

Index No. 2 for Vols. 11-20(1958-67)@ @1.50

Set of both indexes@\$2.00

Order from Society for Range Management, 2120 So. Birch Street, Denver, Colorado 80222. 